\title{
Girolamo Muziano, Scipione Pulzone, and the First Generation of Jesuit Art
}

\author{
John Marciari \\ The Morgan Library \& Museum, New York \\ jmarciari@themorgan.org
}

\begin{abstract}
While Bernini and other artists of his generation would be responsible for much of the decoration at the Chiesa del Gesù and other Jesuit churches, there was more than half a century of art commissioned by the Jesuits before Bernini came to the attention of the order. Many of the early works painted in the 1580 s and gos are no longer in the church, and some do not even survive; even a major monument like Girolamo Muziano's Circumcision, the original high altarpiece, is neglected in scholarship on Jesuit art. This paper turns to the early altarpieces painted for the Gesù by Muziano and Scipione Pulzone, to discuss the pictorial and intellectual concerns that seem to have guided the painters, and also to some extent to speculate on why their works are no longer at the Gesù, and why these artists are so unfamiliar today.
\end{abstract}

\section{Keywords}

Jesuit art - Il Gesù - Girolamo Muziano - Scipione Pulzone - Federico Zuccaro Counter-Reformation - Gianlorenzo Bernini

Visitors to the Chiesa del Gesù in Rome, or to the recent exhibition of Jesuit art at Fairfield University, ${ }^{1}$ might naturally be led to conclude that Gianlorenzo

1 Linda Wolk-Simon, ed., The Holy Name: Art of the Gesù; Bernini and His Age, Exh. cat., Fairfield University Art Museum, Early Modern Catholicism and the Visual Arts 17 (Philadelphia: Saint Joseph's University Press, 2018).

(C) JOHN MARCIARI, $2019 \mid$ DOI:10.1163/22141332-00602002

This is an open access article distributed under the terms of the prevailing CC-BY-NC license at the time of publication. 
Bernini (1598-1680), Giovanni Battista Gaulli (1639-1709), and the artists of their baroque generation were the Jesuit artists par excellence. That conclusion might not actually be wrong, in fact, for that style of the seventeenth century would be used to outfit most Jesuit churches in Italy and beyond. And yet, we should recall that the Society of Jesus was founded back in 1540 , that the Gesù was built between 1568 and 1584, and that there was more than half a century of art commissioned by the Jesuits before Bernini came to the attention of the order. This first generation of Jesuit art has not, however, fared well. Most of the works painted by these artists for the Gesù in the 1580 s and gos are no longer in the church, and some do not even survive to the modern age. $^{2}$

Perhaps even more problematically, the Jesuit painting of the first CounterReformation generation has been the subject of particular scorn on the part of scholars and critics. Indeed, the "Counter-Reformation artist" label has been the kiss of death for an Italian painter, as the words "Counter-Reformation" have conjured up a range of evils: the Roman Inquisition and the Index of Forbidden Books, the restriction of intellectual and artistic freedom. Few historians of early modern Catholicism would maintain these characterizations, ${ }^{3}$ but art historians still confine discussions of post-Tridentine art to a limited set of monuments originally chosen because they fit that old notion of what the Counter-Reformation was like. ${ }^{4}$ In the conventional scheme, works

2 Gauvin Bailey, "The Church of the Gesù in Rome and the First Phase of its Decoration," in Wolk-Simon, Holy Name, 97-108, here 99, notes that only two of the early altarpieces remain in their original locations.

3 For typical new approaches see, for example, John W. O'Malley, Trent and All That (Cambridge, MA: Harvard University Press, 200o) or Kathleen M. Comerford and Hilmar M. Pabel, eds., Early Modern Catholicism: Essays in Honour of John W. O'Malley, S.J. (Toronto: University of Toronto Press, 2001). See also John Headley's “Introduction," in John M. Headley and John B. Tomaro, eds., San Carlo Borromeo: Catholic Reform and Ecclesiastical Politics in the Second Half of the Sixteenth Century (Washington: Folger Shakespeare Library, 1988); Eric Cochrane, ed., The Late Italian Renaissance 1525-1630 (London: Macmillan, 1970); and John W. O'Malley, "A Historiographical Frame for the Paintings: Recent Interpretations of Early Modern Catholicism," in Franco Mormando, ed., Saints and Sinners: Caravaggio and the Baroque Image, Exh. cat., McMullen Museum of Art, Boston College (Boston: McMullen Museum of Art), 19-27.

4 A notable exception to this general trend has come in the explosion of scholarship on Federico Barocci in recent years, for which see especially Stuart Lingo, Federico Barocci: Allure and Devotion in Late Renaissance Painting (New Haven: Yale University Press, 2008); Judith Mann, Babette Bohn, and Carol Plazzotta, eds., Federico Barocci: Renaissance Master of Color and Line, Exh. cat., St. Louis Art Museum and National Gallery, London (New Haven: Yale 
seeming to sacrifice inspiration in favor of didacticism-thus suggesting that post-Tridentine patrons limited artistic creativity-have constituted the canon. The persistence of labels like "Counter-Reformation painting" or "Counter-Maniera," and even the traditional Renaissance-MannerismBaroque structure of art history have reinforced this outdated canon. The very concept of a Counter-Maniera, for example, is predicated on the notion that artists were made to reign in the individualism and inspiration shown in the previous generation. Artistic creation is thus defined in negative terms: an explanation of art by resource to what it is not. Such a view is necessarily myopic and surely has little to do with the concerns of the artists at the time. $^{5}$

This paper will begin by challenging the traditional canon, by choosing monuments based on criteria such as the prominence of commissions or the successful careers of the artists. My concern here is mainly with the professional painters at the top of the traditional artistic hierarchy, those who received the commissions for the large, multi-figured altarpieces that might be said to represent the taste of the artistic establishment in later Cinquecento Rome. There is no guarantee that such an approach will select monuments that best embody the desires of reforming patrons, but realistically, there can be no single definitive account of religious art in later sixteenth-century Rome. Even in one city at one time, there was no monolithic Counter-Reformation, a point that becomes clearer with every new study of the period; indeed, the attempts to boil down early modern Catholicism into a single entity have been the cause of much misinterpretation. Given that even the Gesù altarpieces have little stylistic consistency, for example, and that they are very different from the paintings in the Jesuit colleges, it seems illogical to argue for a single Jesuit style. ${ }^{6}$

University Press, 2012); and Ian Verstegen, Federico Barocci and the Oratorians: Corporate Patronage and Style in the Counter-Reformation, Early Modern Studies 14 (Kirksville, MO: Truman State University Press, 2015).

5 In the introduction to Rudolf Wittkower and Irma B. Jaffe, Baroque Art: The Jesuit Contribution (New York: Fordham University Press, 1972), long the standard work on Jesuit art, Wittkower claimed that "the Society had scarcely any artistic ambitions before 160o," to which Howard Hibbard, "Ut picturae sermones': The First Painted Decorations of the Gesù," in Wittkower and Jaffe, 29-49, here 40, added that "it was the message, not the form or artfulness of the utterance, that interested the great reformers."

6 The Jesuit attitude toward, and effect on, artistic style is a long-standing problem, for which the essential first reference is Wittkower and Jaffe, Baroque Art: The Jesuit Contribution. Although I am interested here in works created for the Jesuits, I will leave the broader problem of synthesizing all Jesuit art and of investigating the link between Jesuits and "the baroque" 
While the Jesuits and other religious orders created an environment of reform in Rome that must have been palpable to the painters, I would contend that painters responded in ways different from those often set out in discussions of the period. The arguments advanced here need not necessarily contradict or replace previous accounts, but rather, are intended to sit alongside them, moving the history of art for Counter-Reformation Rome closer to the multi-faceted image of the Roman Counter-Reformation that historians have detailed in recent decades. There is no single "Counter-Reformation art," but there are paintings that deserve far more attention in any discussion of art in Counter-Reformation Italy or of art for the Jesuits. In sum, my project here, although interested in the relationship of painting to the early Jesuits, might nonetheless be labeled a plea for painters of the era as painters, rather than seeing them firstly as the agents of reformist churchmen and patrons. ${ }^{7}$

Against the background, we should start any discussion of early Jesuit art with Girolamo Muziano (1532-92), whose Circumcision of Christ altarpiece, painted in the late 1580 s (Figure 2.1), was the original high altarpiece at the Gesù. ${ }^{8}$

to others. On the Jesuits and baroque art, see Evonne Levy, Propaganda and the Jesuit Baroque (Berkeley: University of California Press, 2004); Alan Tapié, Baroque vision jésuite: $D u$ Tintoret à Rubens, Exh. cat., Musée des Beaux-Arts, Caen (Paris: Somogy, 2003); Gauvin Bailey, "Le style jésuite n'existe pas': Jesuit Corporate Culture and the Visual Arts," in John W. O'Malley, ed., The Jesuits: Cultures, Sciences, and the Arts, 1540-1773 (Toronto: University of Toronto Press, 1992), 39-44; and Wolk-Simon, The Holy Name. On early Jesuit art, see Hibbard, "Ut picturae sermones"; Gauvin Bailey, Between Renaissance and Baroque:Jesuit Art in Rome 1565-1610 (Toronto: University of Toronto Press, 2003); and Bailey, "The Church of the Gesù in Rome."

7 While Gauvin Bailey has been in many ways the champion of early Jesuit art, my approach to the material differs from his in key ways. Above all, where his investigation looked essentially only at art done for the Jesuits, mine is part of a much broader investigation of Roman art in the Cinquecento, dating back to my doctoral thesis: John Marciari, "Girolamo Muziano and Art in Rome, circa $1550-1600$ " (PhD diss., Yale University, 2000). Moreover, Bailey is slightly dismissive of Muziano's high altarpiece, which he sees as the project of the patron Alessandro Farnese rather than of the Jesuits. I do not believe that the distinction is relevant, for Muziano had not worked for Farnese previously, and if Farnese were to have required that "his" artist paint the high altar, it would probably have been Giovanni de' Vecchi, then in the cardinal's employ.

8 For discussion of the altarpiece, with references especially to its contract and patron, see Carlo Galassi Paluzzi, "La Circoncisione del Muziano nella Chiesa del Gesù (note e documenti)," Roma: Rivista di studi romani 3 (1925): 209-10; Ugo da Como, Girolamo Muziano, 1528-1592: Note e documenti (Bergamo: Istituto Italiano d'Arti Grafiche, 1930), 187; Clare Robertson, Il Gran Cardinale: Alessandro Farnese, Patron of the Arts (New Haven: Yale University 


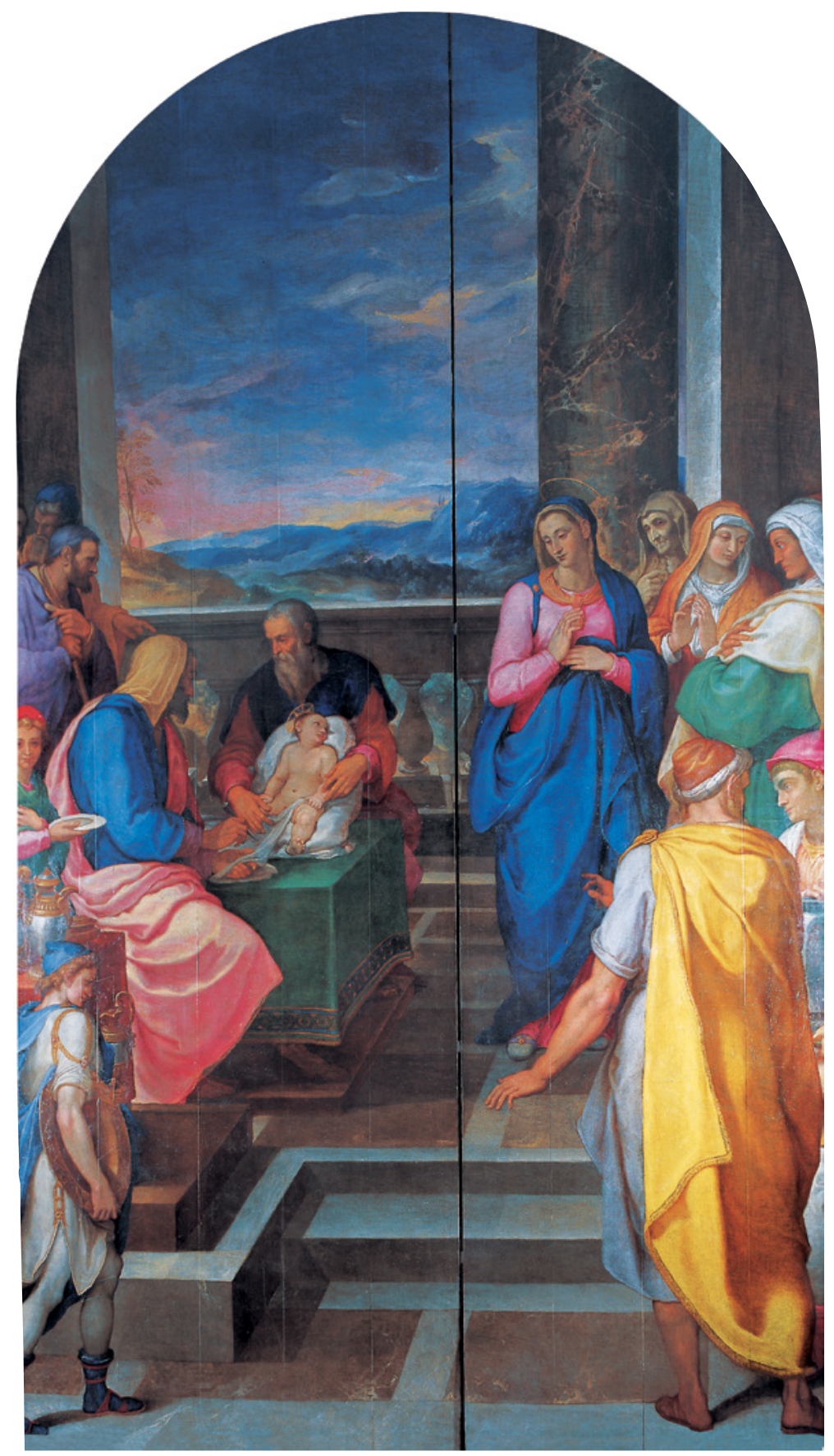

FIGURE 2.1 Girolamo Muziano, Circumcision, 1587-89. Chiesa del Gesù, Rome REPRODUCED WITH PERMISSION OF THE CHURCH OF THE GESÙ, ROME. PHOTO: COURTESY SAINT JOSEPH'S UNIVERSITY PRESS 
As much as any artist of the Renaissance, Muziano is a figure who has fallen through the cracks of art history's floorboards. Born in 1532 in Brescia, he was trained in Padua and Venice before moving to Rome in 1550, where he remained for the rest of his career. Not only is he not a favorite native son for any artistic center, but in the way art history has been written, he fits the paradigm of neither Renaissance nor Baroque, nor even Mannerism, instead working mainly between Michelangelo's death and the arrival in Rome of Caravaggio and Annibale Carracci. He is, in many ways, the artist whom time forgot. In the old standard study of Jesuit art by Wittkower and Jaffe, he receives only passing mention, and even in Gauvin Bailey's book on early Jesuit art, or his recent essay on the first phase of decoration at the Gesù, Muziano is reduced to an ancillary character. ${ }^{9}$

However, despite what might be called the "chronic defect" of Roman patronage, in which tastes changed as rapidly as popes, and artists who were praised in one year might be considered scandalous the next, Muziano remained consistently in favor across a broad spectrum of Roman patrons, over a period of decades. In the 1560 , he was the primary painter to Cardinal Ippolito d'Este (1509-72), responsible for frescoes both in the Este palace at Rome and at the Villa d'Este in Tivoli. He would go on to paint the first two major altarpieces in the new basilica of St. Peter, and the abovementioned original high altarpiece of the Jesuit mother church. He worked, too, for the other new orders of the Counter-Reformation - the Oratorians at the Chiesa Nuova, and the Capuchin offshoot of the Franciscans - and he was responsible for the refounding of the Accademia di San Luca. Little known today, he was arguably the leading artist in Rome from the late 1560 os until his death in $1592 .{ }^{10}$

Press, 1992), 196; Maria Luisa Madonna, ed., Roma di Sisto v: Le arti e la cultura (Rome: De Luca, 1993), 171-73; and Patrizia Tosini, Girolamo Muziano 1532-1592: Dalla maniera alla natura (Rome: Ugo Bozzi, 2008), 455-57.

9 See Wittkower and Jaffe, Baroque Art: The Jesuit Contribution; Bailey, Between Renaissance and Baroque; and Bailey, "The Church of the Gesù in Rome." Likewise, Muziano receives only a passing mention in Thomas M. Lucas, Saint, Site, and Sacred Strategy: Ignatius, Rome, and Jesuit Urbanism, Exh. cat., Biblioteca Apostolica Vaticana (Vatican City: Biblioteca Apostolica, 1990) and is unmentioned in Mormando, Saints and Sinners, an exhibition dedicated to Jesuit and Counter-Reformation art. He is illustrated but not discussed in Bailey, "Les premières décorations du Gesù," in Tapie, Baroque, vision jésuite.

10 Muziano is, at least, now able to be studied in a proper catalogue raisonné, Patrizia Tosini's Girolamo Muziano 1532-1592, a work that relies heavily on the present author's doctoral thesis (Marciari, "Girolamo Muziano"). Previously, the only published monographs on the artist were Ugo da Como, Girolamo Muziano and Paola di Giammaria, Girolamo Muziano: Brixien pictor in urbe da Brescia a Roma (Rome: Shakespeare \& Company, 1997), 
Time, however, has not been kind to Muziano. Apart from the vagaries of art historical taste, his frescoes in the Este palace at Rome, and many of those at the Villa d'Este, are lost, as is one of his St. Peter's altarpieces, while the other, much damaged, was removed to the church of Santa Maria degli Angeli. At the Gesù, a decision was made in 1834 to rebuild the apse of the church in neo-classical style. Both Muziano's altarpiece and Giacomo della Porta's (1532-1602) tabernacle were removed and replaced in 1841 with Antonio Sarti's (1797-1880) modern project, including the exceedingly dull altarpiece still in place today. Della Porta's tabernacle wound up, improbably, in the cathedral of Thurles, in Ireland. ${ }^{11}$ Muziano's altarpiece was shoved into a narrow corridor that connects the sacristy of the Gesù with the Casa Professa. The top of the altarpiece was cut into a curve so that it could fit into the vaulting of the hallway, and it was probably at this point that the panel was split down the middle, in order to move it. Until the last decade or so, the altarpiece was primarily known only in a murky black and white photograph and was unmentioned by guidebooks; only a really diligent art historian, armed with the knowledge of where the painting was kept and willing to pester the sacristans at the Gesù, would ever manage to see it in the back hallway where it sits.

The old photographs do little, however, to prepare one for the scale and rich color of the painting. It is a massive work, $520 \times 300 \mathrm{~cm}$ (almost eighteen feet high), and seen at the end of the originally whitewashed nave, it must have been striking. The composition as seen today appears a bit odd, with its empty central foreground. This is atypical for Muziano, who tended to concentrate his compositions on the picture plane, but della Porta's Eucharistic tabernacle covered that part of the painting in the original ensemble, as can be seen in Andrea Sacchi's (1599-1661) view of church during the 1640 celebration of the order's centenary. ${ }^{12}$

There are further questions that come to mind. Why the Circumcision of Christ? This had to do with Ignatius Loyola's $(c .1491-1556)$ decision to name the Jesuits after Christ himself. Their mother church was, accordingly, the Holy Name of Jesus. Taking the Jewish circumcision as a parallel to the baptism ceremony in which Catholic infants were given their name, the altarpiece thus

both of which are littered with misattributions and other errors that confuse rather than clarify Muziano's career.

11 See J. D. C. Masheck, “The Original High Altar Tabernacle of the Gesù Rediscovered," Burlington Magazine 112 (1970): 110-13. Documents and a discussion are in Vitaliano Tiberia, Giacomo della Porta (Rome: Bulzoni, 1974), 39.

12 Bailey, Between Renaissance and Baroque, 217, discusses the tabernacle, but he does not seem to have it in mind when he later, 254, criticizes the open center of the painting. 
represented the naming of Jesus. Still, it was a somewhat unfamiliar subject. A Circumcision altarpiece inevitably consisted mainly of some figures grouped in the interior of a temple, and the one constant motif in most contemporary versions was the shedding of blood and cutting of flesh. Jacopo Zucchi's (1541-90) Circumcision of 1575 at the Theatine church of San Silvestro al Quirinale, for example, shows a fairly distraught infant Christ literally under the knife. Federico Barocci's (1535-1612) Circumcision of 1590, painted for the Brotherhood of the Name of Jesus in Pesaro and now at the Louvre, is likewise visceral and draws particular attention, as Bellori notes, to the severed foreskin seen in the golden bowl at left. ${ }^{13}$ Peter Paul Rubens's (1577-1640) 1605 altarpiece for Genoa, also painted in Rome, included a still more graphic description of the event, apparently showing the moment when, with an incision having been made, the rabbi pulls the foreskin away. The point of emphasizing the bloodshed of the circumcision was, according to the Golden Legend, to show that the process of Christ's sacrifice to redeem humanity had begun.

In contrast to all this graphic detail, there is remarkably little happening in Muziano's painting. Rather than showing the details of the climactic moment, Muziano has simply arranged his figures in the temple. The Virgin stands at right, but it is unclear whether Joseph is the priest, the man holding the child, or, most likely, the younger man behind them, who looks across towards Mary. An old man and woman at upper left and right are probably Simeon and Anna, conflating the Circumcision with the Presentation or Purification. Acolytes arrive with platter and ewer, usual props of the circumcision, and we see the interactive emotion between Madonna and Child that is mentioned in the Spiritual Exercises and other Jesuit meditations on the Circumcision. The action, however, is all still to come. Christ has not even been uncovered; we do not have the ostentatio genitalium for which Leo Steinberg conditioned us to look, much less a severed and bloody foreskin. ${ }^{14}$ What, then, is happening in Muziano's painting? Why should Muziano have left so much up to the viewer's imagination?

It has been frequently been suggested that the altarpieces of the Gesù follow a program loosely based on the Spiritual Exercises of Ignatius of Loyola, but what has not usually been mentioned in those discussions is how little the Exercises offered to the artist. Unlike medieval devotional texts that described

\footnotetext{
13 Giovanni Pietro Bellori, Le vite de' pittori, scultori, et architetti moderni (Rome: Mascardi, 1672), 182-83.

14 Leo Steinberg, The Sexuality of Christ in Renaissance Art and in Modern Oblivion, 2nd ed. (Chicago: University of Chicago Press, 2006).
} 
Christ's life and death in exacting and gory detail, Ignatius's passage on the circumcision says only the following: "First: They circumcised the Child Jesus. Second: His Name was called Jesus, which was called by the Angel, before He was conceived in the womb. Third: They gave back the Child to His Mother, who had compassion for the Blood that came from her Son."15

The Spiritual Exercises were meditations on the life of Christ, but Ignatius left the reader-or in the case at hand, the painter-to create the scene. The Jesuits were masters of rhetoric, but, as Roland Barthes has noted, Loyola's text is "purified of any contact with the seductions and illusions of form [...]. [It is] barely language: it is a simple, neuter path."16

Rather than a direct communication of author to reader, the Exercises necessarily engender a new, subjective, imaginative, type of language. Ignatius provides memory points and describes how to imagine, but the images to be imagined are absent from the Exercises. "Actual imagining is the retreatants' exercise."17 Such an approach is neither the creation of, nor limited to, Ignatian writings. Rather, this development in meditation and exegesis reflect broad Cinquecento changes in education, theology, and even in the pattern of reading printed texts, an evolution of what might be called "the technologies of imagining." ${ }^{\prime 18}$

We come away from Ignatius as soon as we begin looking at images, for Ignatius deliberately declined to provide even the description of an event, ${ }^{19}$ but we see in Muziano an approach to image making that had the same relation to visuality that the Spiritual Exercises had to language. As Ignatius left much of the imagining to the retreatant, so too Muziano left the animation of the painted images, the filling in of details and of emotions, to the viewer of his works. This is not to say that Muziano devised this style through a

15 Ignatius of Loyola, The Spiritual Exercises of St. Ignatius of Loyola, trans. Elder Mullan (New York: P. J. Kenedy and Sons, 1914), 136.

16 Roland Barthes, Sade Fourier Loyola, trans. R. Miller (New York: Hill and Wang, 1976), 39-40.

17 Antonio T. de Nicolás, Powers of Imagining: Ignatius de Loyola; A Philosophical Hermeneutic of Imagining through the Collected Works of Ignatius de Loyola (Albany: State University of New York Press, 1986), 41.

18 Nicholás, Powers of Imagining, xx-xxi, 7. John W. O'Malley, "Early Jesuit Spirituality: Spain and Italy," in Christian Spirituality III: Post Reformation and Modern, ed. Louis Dupres \& Don E. Saliers (New York: Crossroad, 1989), 3-27, similarly notes that the Exercises rely on a kind of affective psychology. See also Pamela M. Jones, Federico Borromeo and the Ambrosiana (Cambridge: Cambridge University Press, 1992), 65-68.

19 David Freedberg, The Power of Images (Chicago: University of Chicago Press, 1989), 183, makes the same observation about Nadal's books, published in the 159 os. 
reading of Ignatius; quite the contrary, Muziano, like Loyola, fits into the broader cinquecento pattern of change with regard to these technologies of imagining. Fuller explanation for the origins of the style is a complicated matter, beyond the scope of this paper; my intention here is merely to point out the narrative strategies at which Muziano and others had already arrived, and which they used at the Gesù.

The same approach seems to categorize Scipione Pulzone's (1544-98) Lamentation of 1593 for the Passion chapel on the right side of the Gesù, but today in Metropolitan Museum of Art (Figure2.2). This is the sort of picture that Federico Zeri described as arte senza tempo, art without time, painting that rejected popular stylistic tropes and that stripped away narrative anecdotal detail in order to create a devotional, meditative icon. ${ }^{20}$ This would seem to be a painting made almost to avoid comment or criticism. ${ }^{21}$ Yet, in 1594, soon after the work was installed, Pope Clement viII (r.1592-1605) visited the Gesù and upon examining the painting requested that Mary Magdalen should be altered "to have a more devout appearance."22 This comment has long baffled scholars writing on the altarpiece. There is no evidence that the painting was ever altered, however, and it remained in the church for nearly a century before it was removed.

In the deliberately pared down, inanimate scenes of these altarpieces by Muziano and Pulzone, we arguably see the kind of painting that could best be called early Jesuit art. Again, this is not to say that it developed because of the Jesuits, for Muziano and Pulzone used this style elsewhere, and, at least in Muziano's case, in projects before the Gesù. Nonetheless, this fundamentally meditative art suited the devotional practices of the Jesuits. It was appealing, with its bright colors and clear compositions, but lacked a complicating second level of artifice. Like Loyola's own language, these pictures represented a simple path.

As a foil to these paintings, and perhaps as a way of reinforcing Jesuit preferences, we can discuss an earlier altarpiece that Pulzone had painted for the chapel of the Angels at the Gesù. There was an extensive Jesuit literature on the angels, with Robert Bellarmine (1542-1621) and Cesare Baronius (1538-1607) turning their attention to the cult and iconography of the archangels. ${ }^{23}$ While

\footnotetext{
20 Federico Zeri, Pittura e Controriforma: "L'arte senza tempo" di Scipione da Gaeta, 2nd ed. (Vicenza: Neri Pozza, 1997).

21 Sydney J. Freedberg, Painting in Italy 1500-1600, 3rd ed. (New Haven: Yale University Press, 1993), 661, 664, writes that the work conveys "after the first impact, a sense of vacancy."

22 Bailey, Between Renaissance and Baroque, 211, 346n165.

23 On the Angels in contemporary writing, see Alessandro Zuccari, Arte e committenza nella Roma di Caravaggio (Turin: RAI, 1984), 120-21; Alessandro Zuccari, "Bellarmino e la prima
} 


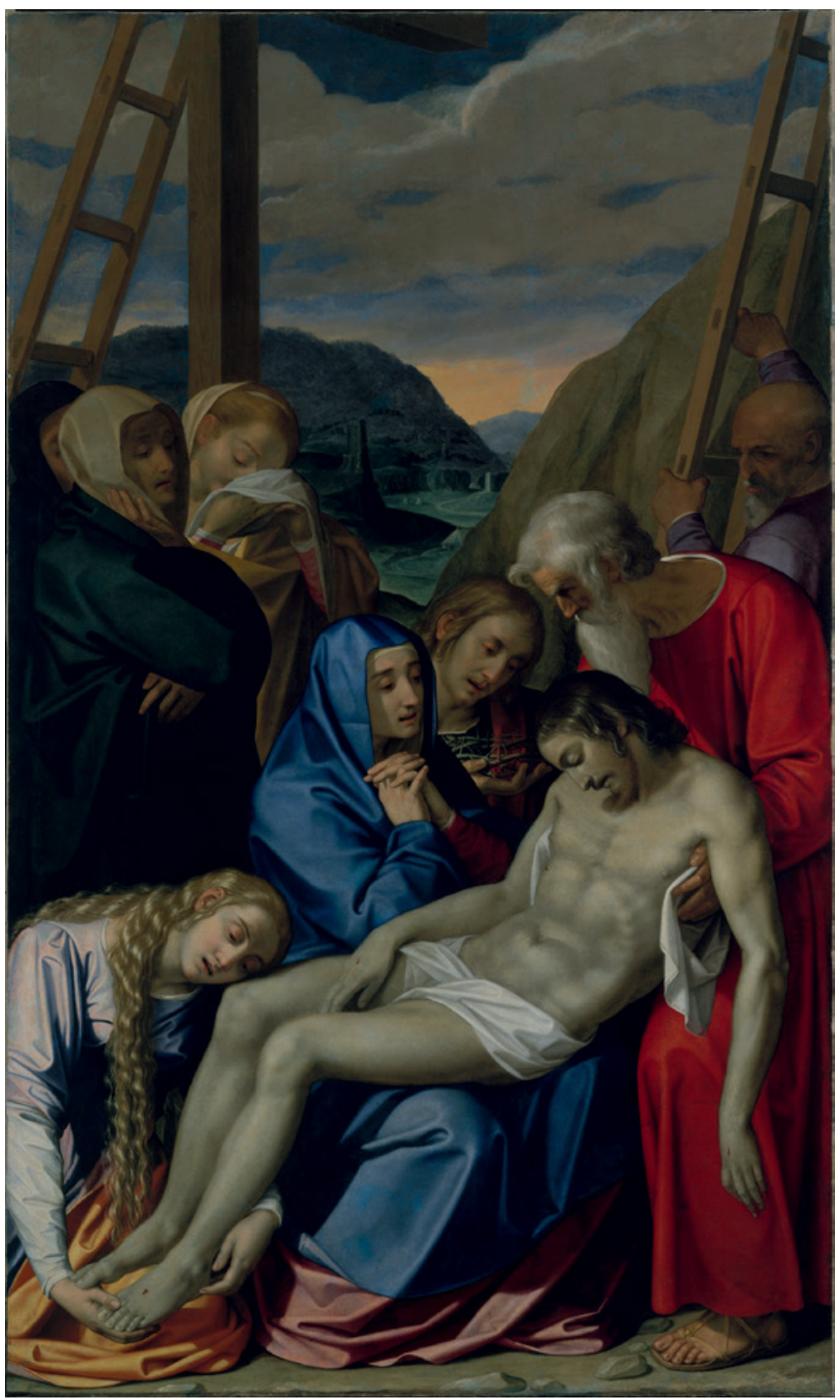

FIGURE 2.2 Scipione Pulzone, Lamentation, 1593

METROPOLITAN MUSEUM OF ART, NEW YORK 
the new Jesuit order did not at this point have saints to whom their chapels might be dedicated, there was a program at the Gesù that reflected Tridentine doctrine and the Jesuit patrons. ${ }^{24}$ In any case, Pulzone received the commission to paint the altarpiece for the Angel chapel in 1588 and probably completed it before 1593, when he painted the Lamentation, now in New York. ${ }^{25}$ His Seven Angels altarpiece was, however, replaced by an altarpiece of 1600 , and is lost. The reasons for the painting's removal and substitution are worth investigating.

A decree that followed Pope Clement viII's 1594 apostolic visit to the Gesù stipulated that the "angels be decently covered" in Pulzone's altarpiece. ${ }^{26}$ Presumably, they must have been nude or nearly so. An engraving by Hieronymus Wierix (1553-1619) is proposed in most accounts of the chapel as recalling Pulzone's altarpiece, but given that Wierix's angels are all completely clothed, there seems little reason to think that the print echoes anything more than the subject. ${ }^{27}$ Putting it aside as an image of Pulzone's painting, we can turn to the slightly different account of the altarpiece given by Giovanni Baglione (1566-1643), who writes that Pulzone's angels were "beautifully painted, but because they were taken from life, representing various people known to all, the picture was removed to avoid scandal. ${ }^{28}$ We are reminded of the scandal

iconografia gesuitica: La Cappella degli Angeli al Gesù," in Bellarmino e la Controriforma, ed. Romeo De Maio et al. (Sora: Centro di Studi sorani Vincenzo Patriarca, 1990), 6o9-28; and Bailey, Between Renaissance and Baroque, 68-71 and 242-45.

24 At the Chiesa Nuova there was an ever closer attention to subjects and iconography; see Costanza Barbieri, Sofia Barchiesi, and Daniele Ferrara, Santa Maria in Vallicella, Chiesa Nuova (Rome: Fratelli Palombi, 1995) and Daniele Ferrara, "Artisti e committenze alla Chiesa Nuova," in La regola e la fama: San Filippo Neri e l'arte, Exh. cat. (Milan: Electa, 1995), 108-29.

25 Bailey, Between Renaissance and Baroque, 214, cites a newly discovered payment of 2.3 scudi on March 12, 1592 for "canvas for the altarpiece of the angels chapel" and concludes that Pulzone's altarpiece was only then begun. The artist had, however, already received over three hundred scudi for the chapel, although the frescoes were little advanced; the other chapels, moreover, tended to have the altarpieces complete before the frescoes. Finally, it would be unusual for Pulzone to have been given the commission for the Lamentation before the earlier commission for the Angels was even under way. Despite the apparent conclusiveness of the canvas payment, the chronology seems far from certain.

26 Alessandro Zuccari, "Bellarmino e la prima iconografia gesuitica," 613-14.

27 See, for example, Wolk-Simon, Holy Name, 474-76, cat. 31 .

28 Giovanni Baglione, Le vite de' pittori scultori et architetti... (Rome: Andrea Fei, 1642), 54. Bailey, Between Renaissance and Baroque, 212, dismisses Baglione as "merely garbling the story." 
around Caravaggio's Death of the Virgin, in which the figure of the Virgin was said to be recognizable as a prostitute who served as a model.

The issue with Pulzone's Angels might lie somewhere between Baglione's account and that suggested by the apostolic visit - that is, there was a problem in the combination of nudity and naturalism. On the one hand, scantily clad angels were hardly uncommon in Cinquecento Rome, and with the Jesuit painter Giuseppe Valeriano (1542-96) also working on the Angels chapel, the basic iconography of the angels (i.e. their degree of undress) must have been acceptable, for Pulzone's altarpiece was installed in the chapel. On the other hand, other artists of the time had used a naturalism that made their models were recognizable. There are also contemporary paintings like Jacopo Zucchi's Mass of Saint Gregory in SS. Trinità dei Pellegrini, for example, which deliberately import portraiture into religious narrative. Pulzone's naturalism, however, meant that nude models (not subjects of portraiture) could be recognized. In the 1580 s, Pulzone was distinctly not the painter of arte senza tempo, but on the contrary, a naturalist in the mode of Santi di Tito (1536-1603), someone whose figures could have a palpable, current-day presence.

To get a more concrete idea of what this means, let us look at the Assumption of the Virgin that Pulzone had painted in 1585 for the Bandini chapel in the Theatine church of S. Silvestro al Quirinale (Figure 2.3). The Assumption was another picture designed with careful attention to Tridentine reform, and we find a focus on iconography typical of the moment. In April of 1583 , that is, before Pulzone began painting, Silvio Antoniano (1540-1603) and Bishop Gabriele Paleotti (1522-97) in Bologna discussed the work in a series of letters. They considered the presence of angels at the Assumption and the juxtaposition of the Assumption with the depiction of the apostles at the empty tomb below; these were two separate events, but it was agreed that so large an altarpiece would look empty without the apostles, who were, moreover, expected because of the usual custom of painters. Paleotti specified that the angels could be present, but that there would have been only eleven apostles (James the Greater having died), and that some should be looking at the tomb, while others might look upward "being able to see the miracle because of the power of the Holy Spirit." Regarding the age of the Virgin, young or elderly, Paleotti wrote that he was not able to make a pronouncement. Despite the letters, Pulzone's altarpiece had twelve apostles, also following the usual custom in painting. ${ }^{29}$

29 The documents, first published by Paolo Prodi, "Ricerche sulla teorica delle arti figurative nella riforma cattolica," Archivio italiano per la storia della pietà 3 (1962): 123-88, are summarized by Maria Barbara Guerrieri Borsoi in Madonna, Roma di Sisto v, 266-67. Ferrara, "Artisti e committenze alla Chiesa Nuova," 110 and 125, rightly points out that the concerns 


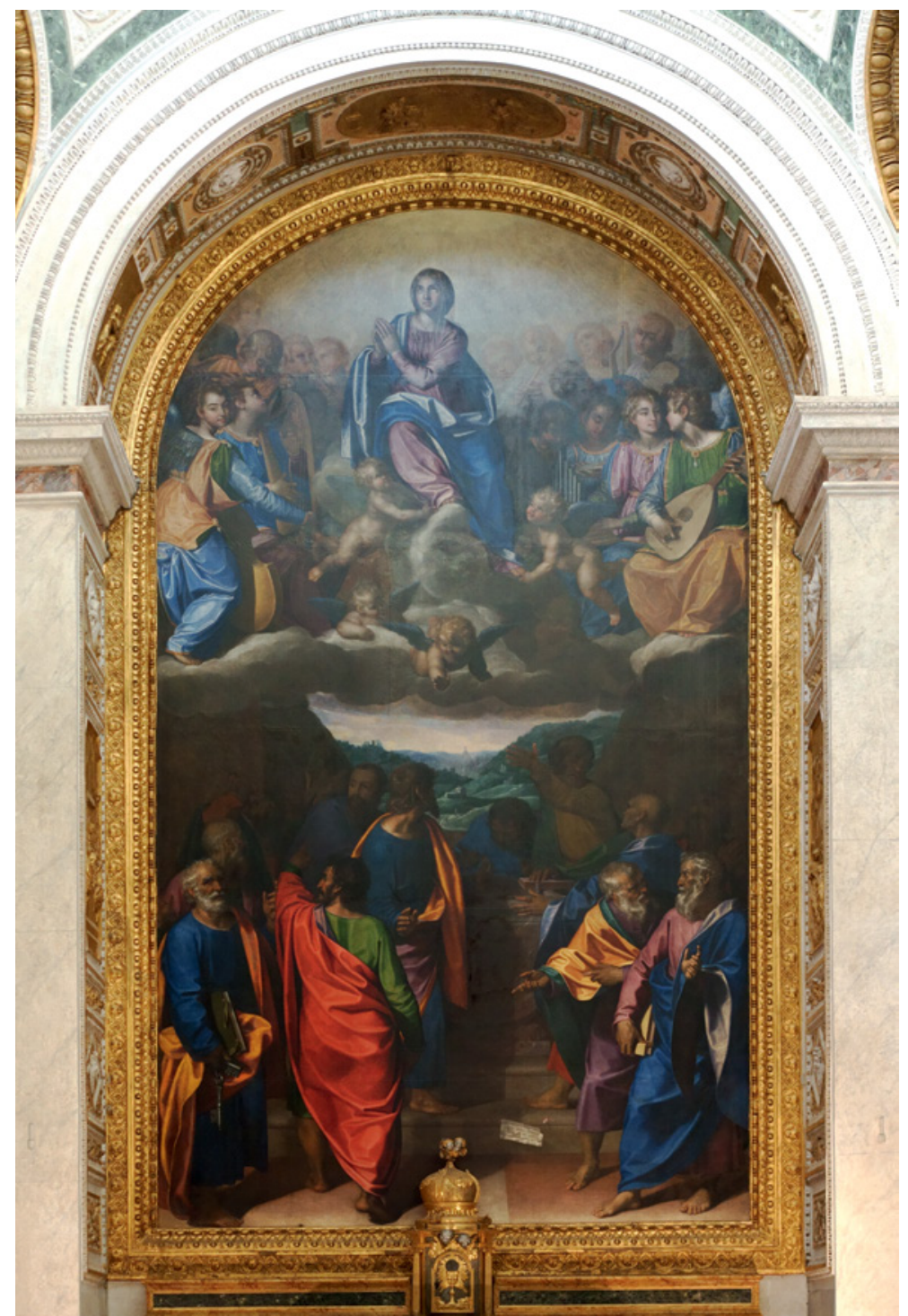

FIGURE 2.3 Scipione Pulzone, Assumption of the Virgin, 1585. S. Silvestro al Quirinale, Rome

Returning to the question of naturalism, and the links to the Angels altarpiece from the Gesù, it is worth again quoting Baglione, who described the Assumption as having "some beautiful angels taken from life," using the same phrases

of the patrons and the intervention of Antoniano were related to the iconographic debates at the Chiesa Nuova, where Pulzone was also working. 
that he would use to describe the lost Gesù Angels. ${ }^{30}$ Obviously, Baglione does not mean that Pulzone saw real angels, but rather, that he painted his angels from live models. In contrast to the Gesù altarpiece, however, in which the angels had sufficiently little clothing to draw notice, those in the S. Silvestro painting are all fully clothed. At the Gesù, again, the combination of naturalism and nudity was evidently the problem. The angels must have seemed to some viewers like nude or semi-nude portraits. The issue was decorum, and the simplest remedy was to add clothing. It is impossible to say whether this was ever done, although given the relatively complete record of work in the church we might expect to find some reference had it happened. In any case, the painting was replaced by 1600 but before that time, one imagines, it must have been of great interest to the young Caravaggio, who would afterwards adopt similar strategies of confrontational naturalism. In contrast to the affectless, quasi-artlessness of the iconic mode seen in Muziano's Circumcision and Pulzone's Lamentation, the Angels with its naturalism and nudity must have seemed to move painting out of the world of ideas and into the world of the viewer. The work that ultimately replaced it, Federico Zuccaro's (1539-1609) The Seven Archangels in Adoration of the Trinity (Figure 2.4), stripped away that confrontational naturalism and offered instead a frankly, perhaps deliberately, banal vision; even by the most negatively defined standards of CounterReformation painting, this is a saccharine and boring altarpiece. The academic Zuccaro, of course, was also dead set against Caravaggio's pictorial strategies, but his coldly academic Angels seems an ill-advised retort to those.

Moreover, naturalism of that sort is largely absent from the painting that Pulzone made immediately after the Angels: the Lamentation. Conceivably, the Angels began to evoke questions almost immediately, even before the 1594 apostolic visit, and one wonders whether Pulzone, to avoid criticism, began to modify this more illusionary naturalism in his altarpieces, leading to the sober style of the Lamentation, where he moved towards the abstracted style familiar in the works of Muziano. The Annunciation and Assumption painted around the same time by Giuseppe Valeriano for another chapel in the church are a further echo of the devotional mode, of painting that does not complicate devotional imagery by mixing it with the world of the viewer. ${ }^{31}$

Thinking ahead into the developments of Seicento painting, however, Muziano and Pulzone may have represented a sort of dead end, and despite Zuccaro's late essay in an analogous style with his Angels altarpiece, painting was moving on to different concerns. Even if we consider Annibale Carracci (156o-1609)

30 Baglione, Vite, 53 .

31 For the paintings, see Wolk-Simon, Holy Name, 121-22. 


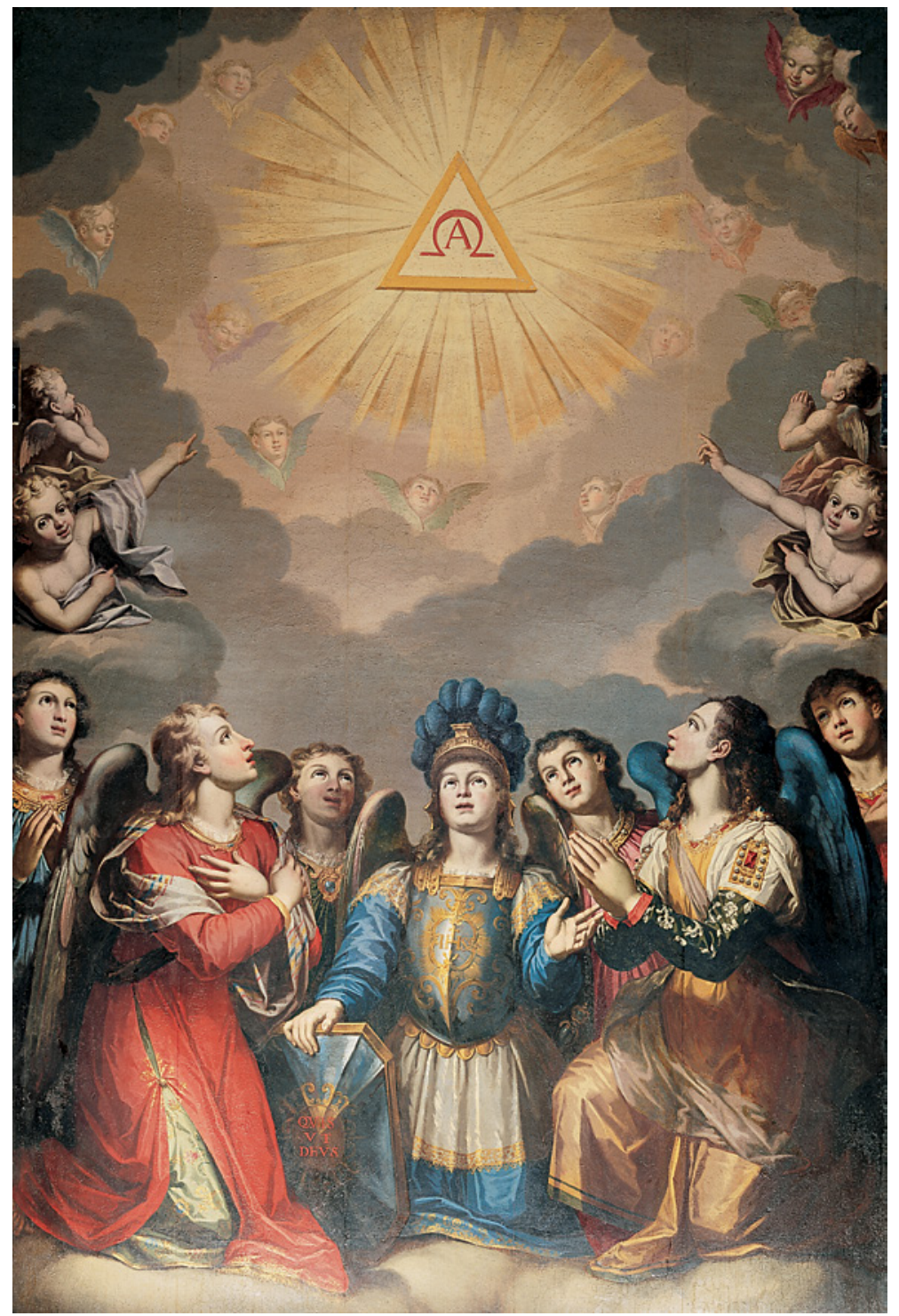

FIgURE 2.4 Federico Zuccaro, The Seven Archangels in Adoration of the Trinity, 1600. Chiesa del Gesù, Rome REPRODUCED WITH PERMISSION OF THE CHURCH OF THE GESÙ, ROME. PHOTO: COURTESY SAINT JOSEPH'S UNIVERSITY PRESS

and Caravaggio (1571-1610) as opposing poles, both grounded their art in naturalism. Caravaggio would never work for the Jesuits, but as the century progressed, and as the Jesuits themselves evolved in their second century, they would move away from the iconic, devotional style that was used to decorate 
their church in the first generation, and towards the theatrical baroque of Bernini and Gaulli. In the early stages of decorating the Gesù, however, one closer to the time of Ignatius Loyola (and to his own stripped down language, and his aversion to the use of organs or singing in the liturgy), the almost antitheatrical works of Muziano and Pulzone would seem to have presented an ideal model for a Jesuit art.

\section{Acknowledgement}

For the symposium held on April 5-6, 2018 in connection with the exhibition The Holy Name: Art of the Gesù; Bernini and His Age, Linda Wolk-Simon asked me to revisit the material discussed here, which I had worked on some fifteen years earlier but for various reasons never published. I am grateful to Linda for that invitation, and then to Alison Fleming and Robert Maryks for the invitation to publish a version of the paper here. 